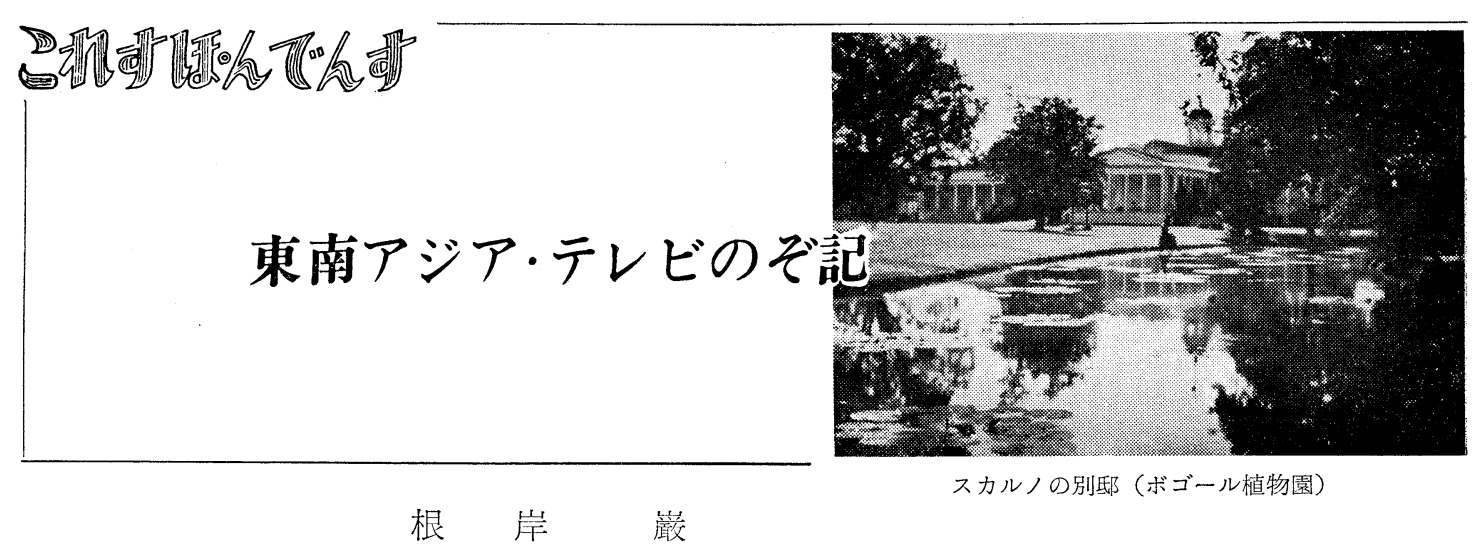

\section{9. ジャカルタへ}

マニラからジャカルタへの 2 時間半は，ガルーダ9を その象徴とするインドネシア航空を使うととになってい た. UNESCO のミッションとしては，ある1国を訪問 するとき，往復の少なくともその片道は，できるだけそ の国の航空便を使うととになっているようである. 国 連という寄合い世帯はスポンサーに平等に義理立てをす る必要があるのだろう，とうして，バンコクからペナ ンへはマレーシア航空, シンガポールからマニラへは PAA. そしてジャカルタへはインドネシアのガルーダ. ジャカルタからバンコクへ帰るとき亿は SAS をチャー ターしているタイ航空. シンガポールまでは SAS のサ 一ビス，それからはタイのサービスと，ホステスから料 理, ナプキンまで交代である.とうして 6 力月, 9 力国 を巡った間に飛ぶこと24回で，乙の5社のほか，IAL, PIA, アリアナ (アフガニ航空), キャセイ, BOACそ れに JAL(下手するとCAT にも乗るはずだった)，台 渌の国内線を入れると13社の世話になった。 とうして各 社の飛行機に乘って見ると, その内装や料理, サービ ス, 搭乘員の服装, 言葉, 客扱いなどを比べてみるのも おむしろい，妻はさっそく，ナプキンやスプーン，箸, そのお国ぶりを表わすちょっとしたサービス品の類を, ねだりながら集めていた。

なかでもアリアナとガルーダはおえまつで，機内はほ こりっ涩く, 実のところ, 乗るまでは不安を感じたほど だったととを，いまは申わけなく思うばかりである。

われわれミッションの経費は，各国にあるUN・TAB

9）ガルーダはシバ神の使者とい放れる神鳥. インドネシアの国章にも 「伝統」の意味にガルーダが使われている.この国の国章蛙，ガル 一ダがその両足で Bhinneka Tunggalika (ビンネカ・トンガリー カ：多㥞性の統一）と記した布をふん来克，信仰・民族・人道・民 主・社会主義の 5 大綱領(パンチャシラ)の盾を守っている，盾の中 央の赤い横線は赤道を象徵し，その上下に，金星(自由), 水牛（民 族)，稲穂と綿(福社)，飾り輪(男女平等)功配してある.
を通してまかなわれ, 調査上の連絡やホテルのめんどう あ，それぞれの国の UN・TAB にまかせていた，そん な関係で, 空港へは UN・TAB の人が出迎えてくれ, 入国手続きから手荷物の受取りまでの一切をやってくれ た、私達はただ彼の後について歩けば自然に OKになる 仕組みであった。

ジャカルタ空港であ「誰か来ているか」と, それらし き人をキョロキョロ挆していた私の後から「ネギシサー ン」と, まさしく日本人の声である. ふり向くとそこに 日本人がいる. 差し出された名刺を見ると, UN・TAB の北谷とある.「日本人がいてくれる」という安心感に一 時に疫れが出てきた，東南アジアの UN 関係にはイン ド人が多く，日本人は特に少ないと聞いて来たが，その 少ない日本人のうちの 2 人, ECAFE の赤谷さんとこの 北谷さんには本当にお世話になり通しだった. インドネ シアが国連を去った今日，北谷さんはどうされたか，筆 を走らせながらそんなととを考えたりする。

空港は街の東北で, 宿所のインドネシア・ホテルは西 南. 私達の車は, 夕やみのジャカルタの街へあぐりこん だ、すぐりこんだ，という言葉があてはまるほど，通り はまだ整わず，ホコリっぽくゴミッぽい，その両端をア リの行列よろしく, 実に多くの人人がザワザワと往き来 し，たむろし，ざわめいていた，その人影のすき間から アセチレン灯がチラチラと見えかくれする様は, 日本の 夏祭の宵の風情である.

その人の動きは，流机るように，うごめくようにゆる やかである.フィリピンであマラヤでも, タイでもまた インドでもパキスタンであそれは同じであった。 あても なくただ歩きあてもなく立ち止まって遠くを見やり， ただ集まっては声高に話に花を咲かせる、インドネシア やインドでは, 疲れ果てたかのようにしゃがみ込んでい る群もいる，一五ょうど終戦後 $1 ， 2$ 年の頃にわれわ れがしたような格好で. 


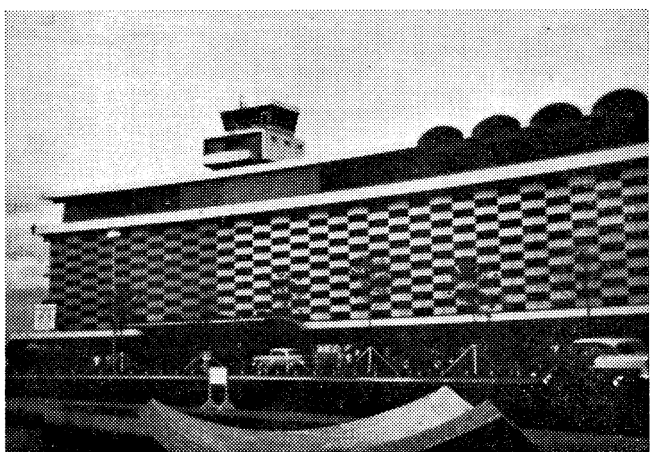

インドネシア・ホテル：日本の資材と技術ででき た14階建の豪華なむの. 建物は大成建設, 内装は 松阪屋, その祝賀式のあいさつにスカルノはイン ドネシアの力を賛えたが，日本のことには一言も ふれなかった。

バンコクで，「歩く姿を見れば日本人はすぐわかる」 と聞いたことがある. カサコソと前こでみになって足早 やに歩くからで，その姿を彼らは「バッファロー」と呼 ぶのだそうだ.

全く南方の人人はゆったりと歩く、暑いせいもあって 一時にエネルギーを出しては力が続かないのかも知れな い，乙の姿勢と頭に荷を乗せる習性とあいまって，南方 の人人，ことに婦人の姿勢は立派である。いかに勤勉だ からといってお，前てごみにカサコソと歩く日本人の 姿は，強烈な太陽の光を背景にしては，いがも貧相に 見える。

やがて車は，街の中央部を流机る—というより淀む チリ・ウン河(Kali Tjiliwung)，その河筋に市民のマン ディ(沐浴)の姿を見ながら走る，在留邦人仲間がチリ・ ウンコ河と呼ぶその名の起りの姿も目に入ってくる. 中 央郵便局やムルデカ(独立)宮殿と呼ばれる大統領官邸の ほとりを過ぎると，やがて右手にラジオ・インドネシア や博物館, 左手にムルデカ(あとガンビル) 広場 (Medan Merdeka), $1 \mathrm{~km}$ 四方むあろうか之思われるムルデカ広 場は，パレード用に拡張のため目下整地中之ある。そこの 一隅, 道路に面して, 浱緑に塗りたてたピカピカ光る戦 車や大砲の列は，国民に国威を示すつありでもあろう か. それにもう一つ，いたるところに記念碑が目につ

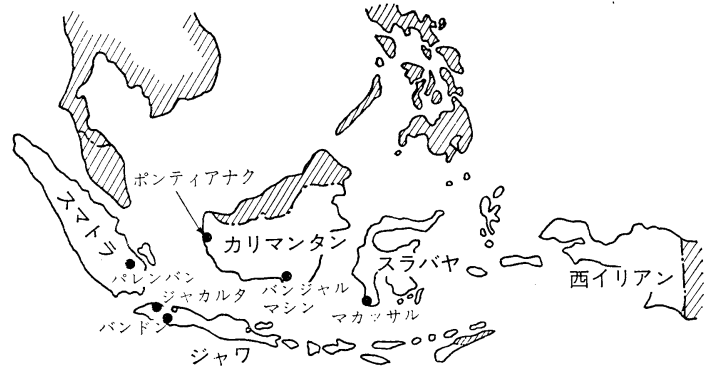

第 19 巻 第 8 号

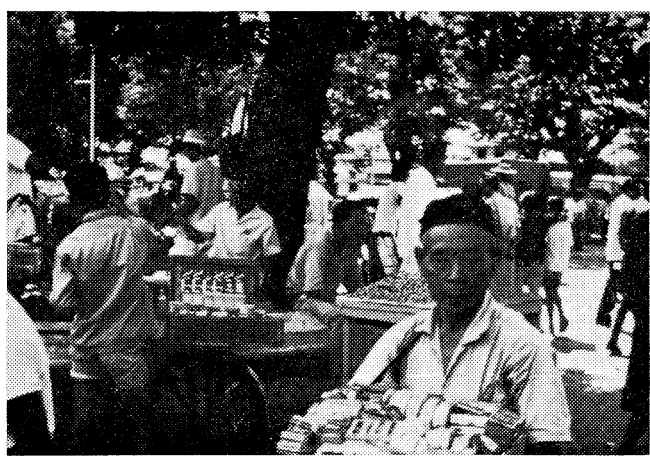

スカルノ帽の物壳り（ジャカルタ）

く，この広場には独立記念碑がたち，との広場のすぐ東 北汇ある広場には西イリアン戦勝記念碑を目下建設中で ある、インドネシア・ホテル前の広場に立つ，青空を仰 ぎ見る青年男女の像は，マレーシア建国の日に焼打ちさ れたというすぐ前のイギリス大使館の残骸と，いい対照 を示している．新興国家の国威を誇るためかむしれない が，被植民地時代に植えつけられた習慣だろう，東南ア ジァ各国には，交叉点といい，広場といい，各種の記念 碑が多すぎる。

\section{0. ラジオ・インドネシア}

Radio Republik Indonesia(RRI) は政府の一部局で， インドネシアのラジオ放送を一手に引き受けている。 そ こを訪㸚た日はちょうど, RRI の新規事業として，テレ ビ放送を始める祝賀式が行なわれていた，RRI では， かつてアジア放送会議で東京に来たととのある Director General のスキルマン(Soekirman) 氏や，前に海外放送 局長だった次長のストヨ（Soetojo）氏と会談した．その 連絡や段取りには,イブラヒム君が大いに尽してくれた. 彼はアジア大会の年 (1962年) のはじめだったか 1961 年 の暮に日本一渡り, 約 1 力年滞在して NHK の中央研修 所で放送技術を研修した人である。つまりは私の教え子 の 1 人である，滞在中彼は拙宅にあ足をはこび，食卓を 囲んだ一夕もある，彼が尽力してくれたというのには， 教え子であること以外の理由があるのである.

インドネシアの事務の運びののろいととは, ジャカル 夕到着早々に, 日本電気の加藤さんから聞かされた。「て の国では 2 倍の日数をとって扮かなくてはだめですヨ」 と彼は言うのだった。それもそのはず, 電話はなかなか通 じないし,街中でタクシーを拾うのも大変なととである。 「電話がかからなくて連絡ができなかった」とか，「車が つかまらなくて遅れてしまった」という理由で，予定が 取り消されたり， 1 時間から 2 時間待ちぼうけをくわさ れたことは 2 度や 3 度ではない，そのため，ついに一日 をすっかりフイにしたととすらある。「電報とは頼信紙

(585) 55 
を飛行機で運ぶことなり」はまだいいとして，「スラバ ヤからジャカルタへ電報を打ったあと, 汽車で出かけた ら, ジャカルタへついた後から電報か配達された」とい うこの国の実情を，イブラヒム君は苦笑いにまぎらすの だった．どうにもいたし方はないと観念してむ，調查が いってうにはかどらないのには、ほんとうに気をむんだ. それに，官庁などの勤務時間は毎日，午前 9 時から午後 2 時まで，金曜は回教のしきたりで11時半でおしまい， そのうえ土曜む半ドンというのだから, ウカウカすると 何もしないうちに 1 週間がたってしまう.

こうして滞在日数も残り少なくなり，困り果てた末， 放送関係のスケジュールと連絡や，資料の収集作成まで の一切をイブラヒム君に頼むと之にした，彼は「てれは インドネシアの恥辱」とばかりにはりきり, 日本で求め たという彼の車をかって，一切を約束どおりに運び，期 限までに資料む整えてくれた．おかげで $1 ， 2$ 日間で 1 週間分の成果をあげるととができたのはもちろんであ る.とんなにもキビキビした人すインドネシアにいるて と，そしてそれが教え子の 1 人であるてとを誇らしくも 感じたのである.

スキルマン氏の話では, RRI で新たにテレビ放送をや るという，ての国のテレビ放送は，すでに政府の別の部 局であるTelevisi Republik Indonesia(TVRI) が電波を 出しているのに, 不合理不経済なととと思ったが, こう した国は人間関係や力の均衡というととが問題になるら しい，—しかし，考えてみれば日本の機構いじりも， いろいろ理屈はつけるが，乙れと似た所があるようであ る.
現在(1964.6), RRI の国内向放送局の数は 38 で総 放送電力は $600 \mathrm{~kW}$ である. 放送局は機能的に, 中央局, 島嶼間連絡局(Inter-Island Station), 地域局 (Regional Station), 地方局(Local Station)に分けられる.

全国的な中央局はジャカル夕にあり，ママカッサル，ジ ヨクジャカルタ, メダンの 3 局が島嶼間連絡局である. 乙のほか，地域局 6 ，地域兼地方局 11 ，地方局 11 があ り，乙の国には総計 28 局がある.しかし現在，てれらの 局のうちの少なくともどれか一つの放送が明瞭に受信で きる地域は，全国の僅か30４0\%にしかすぎない，そし て現在の受信者数は785,010(1961) 以上である.国外放 送としては, ジャカルタに $100 \mathrm{~kW}, 50 \mathrm{~kW}, 20 \mathrm{~kW}$ の短 波 3 局があり，インドネシア語のほか，6外国語をむっ て全世界に向けて放送をつづけている.

受信機工業は微々たるもので，1961年の，年間のラジ 才輸入台数 26,301 台, 国内生産台数 62,259 , 会社数 11 を ピークに，国策が食糧増産一本にしばられたため，年年 下降し，63年には国産台数 14,266 , 会社数 9 となってし まった。

受信機の価格は, 次のようにインフレ傾向沁応じて上 昇し，庶民の手のとどか妪てに止まっている.

\begin{tabular}{|c|c|c|}
\hline & 1962 & 1964.6 \\
\hline 7 石トランジスタ & $2,000 ル ヒ ゚ ア$ & 30,000 ルピア \\
\hline 8 石トランジスタ & 3,500 ルピア & 50,000 ルピア \\
\hline
\end{tabular}

\section{〔筆者の略歴と連絡先〕}

昭 7. 東京帝大電気工学科卒, 以後 NHK 勤務 元：日本放送 協会審議委員 現: 千葉工大講師, 科学放送振興協会副理事長 連絡先・自宅：千葉市春日 1 丁目 6-14 電 (0472) 41-1005

4 月の生産動向統計 電子機械工業会「電子」 7 月号から抜粋

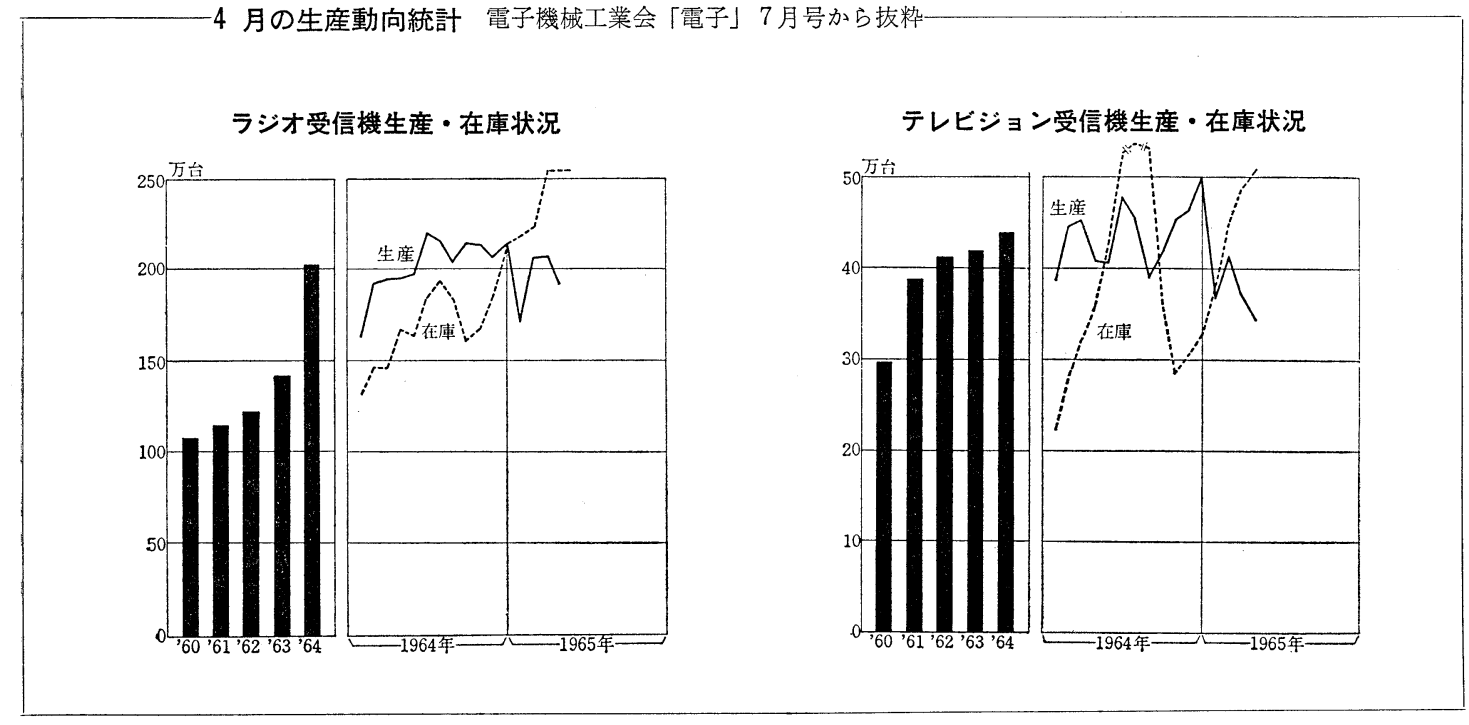

